\title{
A New Measure for Gauging the Riskiness of European Banks' Sovereign Bond Portfolios
}

\begin{abstract}
For a sample of 51 European banks, during 2010-2016, we construct a novel measure (SovRisk) which captures the riskiness of sovereign bond portfolios. We demonstrate the ability of this measure to explain the phases of the European sovereign debt crisis, while accounting for the substantial differences among distressed and non-distressed countries. We contend that SovRisk can be used as complement to bank Credit Default Swap (CDS) spreads, or a substitute in the absence of traded CDS, for measuring banks' sovereign risk.
\end{abstract}

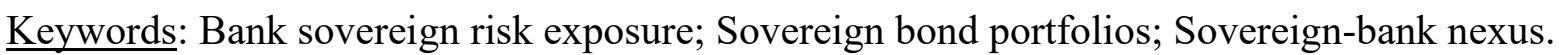
JEL classification: G01; G21; G28. 


\section{Introduction}

The sovereign-bank nexus attracted widespread attention during the European sovereign debt crisis. The strong interconnection between bank and sovereign risk, especially for institutions operating in distressed euro area countries, renewed the focus on the prudential treatment of banks' sovereign bond holdings. ${ }^{1}$ This was of policy importance for both financial stability and monetary policy concerns. Notable contributions (Acharya et al., 2014; Farhi and Tirole, 2017, among others) document the existence of multiple risk transmission channels feeding the twoway vicious loop between banks and sovereigns. Framed within the current debate on how to successfully reduce risk in European banking and complete the post-crisis reform agenda, an accurate appreciation of the inherent riskiness of banks' sovereign bond portfolios is of primary importance.

While an extensive strand of prior literature has focused on investigating the determinants of both size and risk of banks' sovereign debt exposures in Europe (Acharya and Steffen, 2015; Ongena et al., 2019), limited attention has been devoted to develop a measure to quantify the risk associated with these exposures. Previous empirical studies mostly employ CDS spreads to assess the riskiness of both sovereigns and banks and the associated sovereign-bank nexus in Europe (Acharya et al., 2014; Fratzscher and Rieth, 2019, among others). While spreads on CDS contracts have been widely used as proxies for default risk, a number of authoritative contributions (Annaert et al., 2013; Avino and Cotter, 2014; Fontana and Scheicher, 2016) underline significant challenges in using these indicators. In particular, during periods of significant distress CDS spreads tend to capture wider market dynamics and can fail to precisely identify bank riskiness.

In this paper, we create a novel and alternative indicator, SovRisk, which focuses on weighted country-by-country banks' sovereign bond exposures and links these with the specific risk profile of each selected country. Our measure consists of two key components that capture (i) a bank's exposure towards a specific sovereign and (ii) the actual risk of such exposure, is believed to mitigate the controversial effect of wider market dynamics, compared to CDS

\footnotetext{
${ }^{1}$ The existing regulatory framework entails a preferential risk weight for sovereign exposures that are denominated and funded in local currency. Moreover, sovereign exposures are not subject to the limits applied for large exposures or to "haircuts" when they are eligible as high-quality liquid assets (HQLA) within regulatory liquidity standards (BIS, 2017).
} 
spreads, while effectively measuring the overall riskiness of a bank's sovereign debt portfolio. Moreover, while CDS spreads are available mostly for large listed banks, by linking accounting to market-based information, SovRisk can be employed to investigate the sovereign risk exposure for a wider range of banks. ${ }^{2}$ SovRisk can be used to gauge risks for all banks holding sovereign securities and that operate in countries for which information on government bond yields is available. In this paper, we use a publicly available and granular dataset from the European Banking Authority (EBA) and construct SovRisk for 51 banks from 19 European countries. We consider a time frame that covers both a distressed (namely, the European sovereign debt crisis, that started in late 2009) and a more tranquil period, following the ECB's intervention, in mid-2012, to prevent the collapse of the euro area.

We test the reliability of SovRisk in several ways. First, we test its capability to capture the different phases of sovereign default risk that characterised the European context over 20102016. Specifically, we explore whether banks located in stressed (Cyprus, Greece, Ireland, Italy, Portugal, Slovenia and Spain) and non-stressed countries, with heterogenous financial and fiscal conditions, present different risk exposures in their sovereign bond portfolios. ${ }^{3}$ Second, we check whether the trend of SovRisk is similar to that of bank CDS spreads. Finally, in a regression-setting, we explore the relationship between SovRisk and both bank-specific and macroeconomic factors and compare the results to both the evidence for bank CDS spreads and prior literature on bank exposure to sovereign distress in Europe. Our findings demonstrate similar trends in SovRisk and bank CDS spreads, while also highlighting some differences in terms of the main determinants. As SovRisk can be used to quantify sovereign risk exposures for banks that do not have CDS it can be applied to a larger number of institutions. Also our SovRisk measure does not suffer from the aforementioned limitations of CDS quotes, as well as the limitations associated with the use of pure market and/or accounting-based measures (Das et al., 2009).

\section{Empirical methodology and data}

\footnotetext{
2 The use of bank CDS, as highlighted in different contributions in prior literature (Chiaramonte and Casu, 2013; Sclip et al., 2019, among others), has a major impact on sample size, given that only a limited number of relatively large banks have quoted CDS spreads.

${ }^{3}$ Stressed countries, compared to non-stressed countries, were perceived as having higher sovereign default and liquidity risks during the European sovereign debt crisis (Altavilla et al., 2017; Wei et al., 2018). European nonstressed countries are: Austria, Belgium, Denmark, Germany, Finland, France, Hungary, Luxembourg, Malta, Netherlands, Poland, Sweden and United Kingdom.
} 
SovRisk for a bank $i$ at time $t$ is defined as follows:

$$
\text { SovRisk }_{i t}=\sum_{j=1}^{19} \text { Spread }_{j t} * \text { Sovexpcountry }_{i j t}
$$

where:

$$
\text { Spread }_{j t}=1+\left(10 \text { Sovereign bond yield }_{j t}-\text { Benchmark }_{t}\right)
$$

and:

$$
\text { Sovexpcountry }_{i j t}=\text { Sovexp }_{i j t} / \text { Banktotass }_{i t}
$$

Spread $_{j t}$ is the spread between the 10-year yield on a sovereign bond for a country $j$ at time $t$ and the 10-year German bund, as a benchmark. Sovexpcountry $y_{j t}$ is the weighted sovereign exposure of bank $i$ towards each country $j$ at time $t$. The higher the value of SovRisk, the higher the risk of the corresponding bank sovereign bond portfolio. ${ }^{4}$

In a second stage of our analysis, we employ the System-Generalised Method of Moments (SGMM) estimator, two-step procedure, in order to account for the potential endogeneity of the determinants of banks' sovereign bond holdings (Gennaioli et al., 2018; Affinito et al., 2019). The econometric equation is specified as follows:

$$
Y_{i t}=\alpha+\beta_{0} Y_{i t-1}+\beta_{1} X_{i t-1}+\beta_{2} Z_{i t}+\mu_{t}+\varepsilon_{i t}
$$

$Y_{i t}$ is our dependent variable (SovRisk or, alternatively, the logarithm of bank CDS spreads) for bank $i$ at time $t^{5} Y_{i t-1}$ is the lagged value of the dependent variable, included to control for time persistence. Vector X comprises a set of lagged bank-specific variables, commonly employed in the banking literature (for example, Gennaioli et al., 2018; Affinito et al., 2019), as proxies for bank size (Size), loans outstanding (Lending), non-performing loans (NPLs), capitalisation (CET1), profitability (ROE), liquidity (Liquidity), business model orientation (Business model) and solvency (Z-score). Vector Z consists of exogenous country-level factors, such as short-term interest rates (STrate), the amount of sovereign debt (SovDebt) and GDP growth (GDP), able to influence banks' preference to purchase sovereign bonds. Year fixed-effects $\left(\mu_{t}\right)$ are included. Robust standard errors, corrected according to Windmeijer (2005), are clustered at the bank level.

\footnotetext{
${ }^{4}$ The sample considered in this study consists of banks that were subject to either the EBA EU-wide stress tests or transparency exercises during 2010-2016. Table A1 in the Appendix reports the list of banks included in the sample.

${ }^{5}$ We employ bank 5 Y senior CDS contracts collected from Datastream.
} 


\section{Empirical Results}

Figure 1 shows the development of the average value of SovRisk, for the entire sample of banks, during 2010-2016. SovRisk effectively captures the different phases of the European sovereign debt crisis (the right hand side of Figure 1). It peaks during the most acute phase of the crisis, in 2012, driven by a contemporaneous increase in banks' amount and riskiness of sovereign bond holdings, and decreases thereafter. In addition, when splitting the sample between stressed and non-stressed European countries, SovRisk reveals a similar trend. However, its magnitude differs substantially during 2010-2016, with stressed banks holding larger and riskier amounts of sovereign debt compared to non-stressed banks. ${ }^{6}$

In order to provide further evidence on the reliability of our metric, we conduct a visual comparison of the trends for the average values of SovRisk and bank CDS spreads. The test is based on a restricted sample of 32 banks, depending on the availability and reliability of CDS price data (Figure 2). ${ }^{7}$ During 2010-2014, inclusive of the most acute phase of the European sovereign debt crisis, the related trends appear to be similar for both the stressed and nonstressed sub-groups. ${ }^{8}$

The findings for the S-GMM, as displayed in Table 1, demonstrate similarities, but also differences, between the main determinants of SovRisk (column 1) and bank CDS spreads (column 2). Among the similarities, and in-line with prior literature on bank exposure to sovereign distress, our results highlight an inverse relationship between Size and SovRisk, statistically significant at the $1 \%$ level. Smaller banks tend to hold riskier sovereign bonds (Altavilla et al., 2017). In a similar fashion, the findings for bank CDS spreads suggest that larger banks are considered less risky by market participants. ${ }^{9}$ Furthermore, banks with a lower level of NPLs are more prone to increase the riskiness of their sovereign bond holdings, likely because they are subject to less operational constraints and more inclined to "reach-for-yield".

\footnotetext{
${ }^{6}$ T-test of mean differences indicates that SovRisk stressed and SovRisk non-stressed means are statistically different from zero at the $5 \%$ level.

${ }^{7}$ Potential issues in using CDS data are discussed in detail in Mayordomo et al. (2014).

${ }^{8}$ From 2015, for stressed banks, the trends start to diverge. We argue that the introduction of the EU Bank Recovery and Resolution Directive (BRRD), and associated bail-in mechanism, is likely to have played an important role in this evidence.

${ }^{9}$ This evidence could be driven by the fact that large banks are deemed "too-big-to-fail" (TBTF) and, therefore, more likely to benefit from implicit government guarantees in case of distress.
} 
In terms of differences we document a negative and statistically significant (at the $5 \%$ level) relation between bank lending and SovRisk, while the corresponding finding for bank CDS spreads is insignificant (column 2). Samaniego-Medina et al. (2016) find a positive relationship between bank CDS spreads and bank lending. The authors argue that the portion of loans held in a bank's portfolio reflects its liquidity position. The higher the amount of loans, the less liquid the bank and, consequently, the higher CDS spreads. In contrast to this view, however, our result suggests that the asset structure of a bank affects its preference towards risky securities. In this respect, banks that either face lending constrains or limited demand for loans have an incentive to buy more risky sovereign debt in order to support their profitability (Acharya et al., 2015, Altavilla et al., 2017). Finally, among the macroeconomic variables, we find that banks located in countries with larger amounts of sovereign debt (to GDP) are more prone to hold riskier sovereign bonds. This evidence is likely to be driven by the greater "homebias" of the sovereign bond portfolios of stressed banks. The coefficient on SovDebt (for the regression on bank CDS spreads in column 2) is not statistically significant suggesting that bank CDS spreads are not fully explained by increases in sovereign debt (Chiaramonte and Casu, 2013).

\section{Conclusions}

We construct a novel measure (SovRisk) to assess the riskiness of European banks' sovereign bond portfolios. We test its capability to capture the various phases of the European sovereign debt crisis, for both stressed and non-stressed banks. When compared with CDS spreads, we argue that SovRisk represents a reliable indicator of the banks' sovereign risk exposure, which can also be employed in the absence of traded bank CDS. Finally, we find the results of our dynamic panel data regression to be consistent with prior literature on banks' exposure to sovereign risk in Europe, as well as with the evidence for bank CDS spreads. We believe that SovRisk can effectively support supervisory authorities and researchers in assessing banks' exposure to sovereign risk. Moreover, our findings advance the debate on monitoring financial stability in European banking. 


\section{References}

Acharya, V., Drechsler, I., Schnabl, P. 2014. A pyrrhic victory? Bank bailouts and sovereign credit risk. Journal of Finance 69, 2689-2739.

Acharya, V., Steffen, S. 2015. The "greatest" carry trade ever? Understanding Eurozone bank risk. Journal of Financial Economics 115, 215-236.

Affinito, M., Albareto, G., Santioni, R. 2019. Purchases of sovereign debt securities by banks during the crisis: The role of balance sheet conditions. Journal of Banking and Finance, 105575 .

Altavilla, C., Pagano, M., Simonelli, S. 2017. Bank exposures and sovereign stress transmission. Review of Finance, 21, 2103-2139.

Annaert, J., De Ceuster, M., Van Roy, P., Vespro, C. 2013. What determines Euro area bank CDS spreads? Journal of International Money and Finance, 32, 444-461.

Avino, D., Cotter, J. 2014. Sovereign and bank CDS spreads: Two sides of the same coin? Journal of Financial Markets, Institutions and Money, 32, 72-85.

BIS, 2017. The regulatory treatment of sovereign exposures. Discussion Paper, December 2017.

Chiaramonte, L., Casu, B. 2013. The determinants of bank CDS spreads: Evidence from the Financial Crisis. European Journal of Finance, 19, 861-887.

Das, S.R., Hanouna, P., Sarin, A. 2009. Accounting-based versus market-based cross-sectional models of CDS spreads. Journal of Banking and Finance, 33, 719-730.

Farhi, E., Tirole, J. 2017. Deadly embrace: Sovereign and financial balance sheets doom loops. The Review of Economic Studies, 85, 1781-1823.

Fontana, A., Scheicher, M. 2016. An analysis of euro area sovereign CDS and their relation with government bonds. Journal of Banking and Finance, 62, 126-140.

Fratzscher, M., Rieth, M. H. 2019. Monetary policy, bank bailouts and the sovereign-bank risk nexus in the euro area. Review of Finance, 23, 745-775.

Gennaioli, N., Martin, A., Rossi, S. 2018. Banks, government bonds, and default: What do the data say? Journal of Monetary Economics, 98, 98-113.

Mayordomo, S., Peña, J.I., Schwartz, E.S. 2014. Are all credit default swap databases equal? European Financial Management, 20, 677-713.

Ongena, S., Popov, A., Van Horen, N. 2019. The invisible hand of the government: Moral hazard suasion during the European Sovereign Debt Crisis. American Economic Journal: Macroeconomics, 11, 346-379. 
Samaniego-Medina, R., Trujillo-Ponce, A., Parrado-Martinez, P., Di Pietro, F. 2016. The determinants of bank CDS spreads in Europe. Journal of Economics and Business, 86, 1-15.

Sclip, A., Girardone, C., Miani, S. 2019. Large EU banks' capital and liquidity: Relationship and impact on credit default swap spreads. The British Accounting Review, 51, 438-461.

Wei, Y., Hamill, P., Youwei, L., Vigne, S. A., Waterworth, J. 2018. An analysis of liquidity skewness for European sovereign bond markets. Finance Research Letter, 26, 274-280.

Windmeijer, F., 2005. A finite sample correction for the variance of linear efficient two-step GMM estimators. Journal of Econometrics, 126, 25-51. 
Figure 1. Development of SovRisk, 2010-2016.
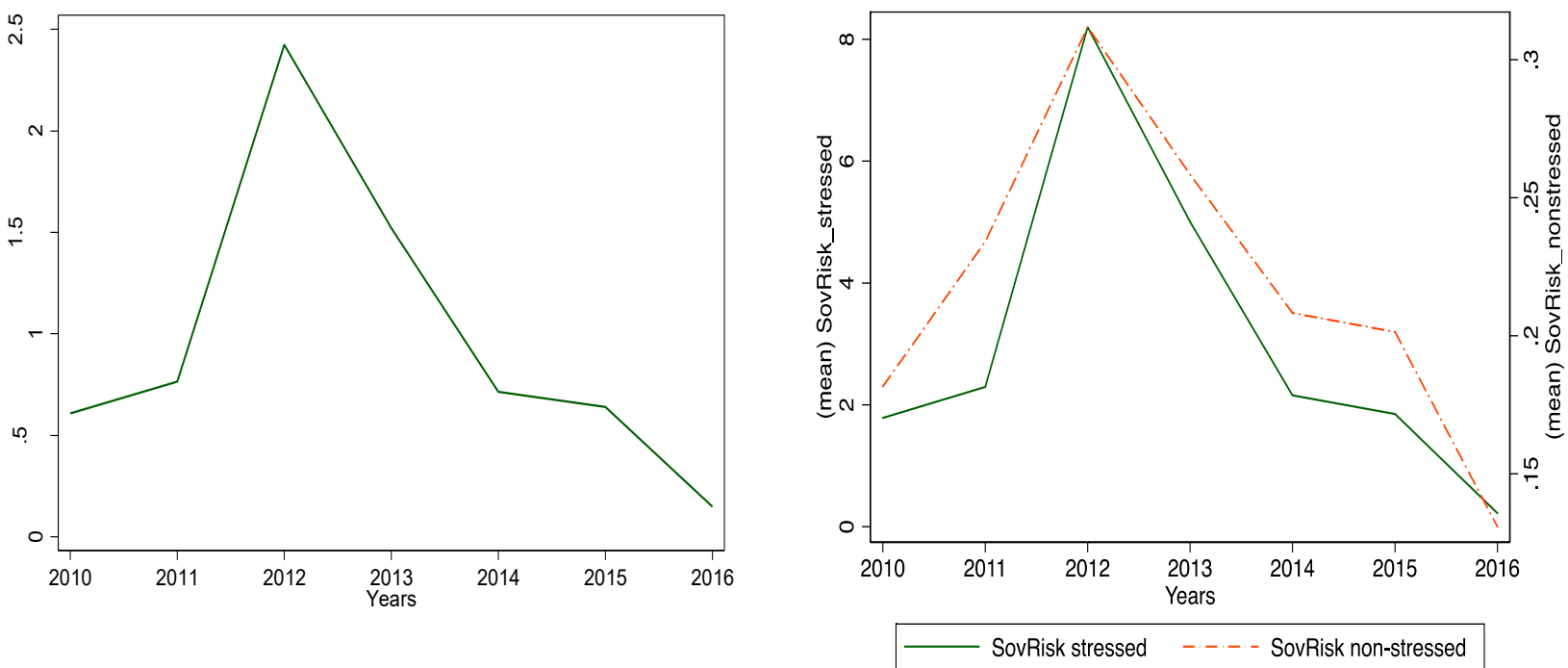

Note: On the left refers the average value of SovRisk for the whole sample, whilst on the right the average value of SovRisk for stressed (green line, left y axis) and non-stressed (dashed red line, right y axis) countries.

Figure 2. Development of SovRisk and bank CDS spreads, 2010-2016.
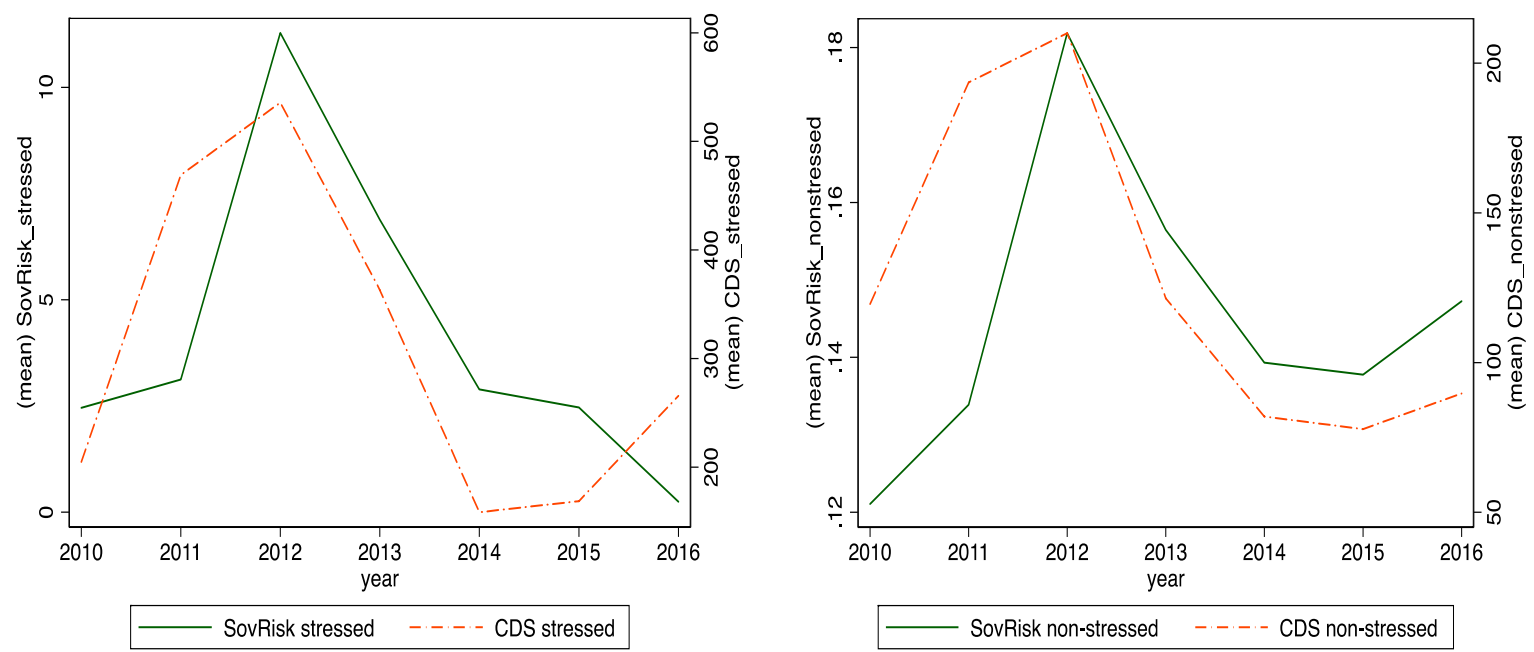

Note: On the left refers the average value of SovRisk (green line, left y axis) and bank CDS spreads (dashed red line, right y axis) for stressed countries, whilst on the right the average value of SovRisk (green line, left y axis) and bank CDS spreads (dashed red line, right y axis) for non-stressed countries. 
Table 1. Riskiness of banks' sovereign bond portfolios (S-GMM), 2010-2016.

(1)

SovRisk

$0.2778 * * *$

$(0.1242)$

Bank CDS spreads $s_{t-1}$

Size $_{\mathrm{t}-1}$

Lending $_{\mathrm{t}-1}$

$\mathrm{NPLs}_{\mathrm{t}-1}$

CET $1_{\mathrm{t}-1}$

$\mathrm{ROE}_{\mathrm{t}-1}$

Liquidity $_{\mathrm{t}-1}$

Business model $_{\mathrm{t}-1}$

Z-score

STrate

SovDebt

GDP

N. Obs.

N. Banks

AR2 Test

Hansen Test

N. Instruments

Year Fe
(2) Bank CDS spreads
0.6500 **

(0.0665)

$-0.0577 * * *$

$-0.0409 * * *$

(0.0098)

(0.0212)

$-0.0016 * *$

$-0.0010$

(0.0007)

(0.0018)

$-0.0030 * * *$

(0.0009)

$-0.0089 * * *$

(0.0023)

$-0.0337$

$-0.7907$

(0.4271)

(0.9457)

$-0.0006$

$-0.0062 * *$

(0.0010)

(0.0010)

$-0.0006$

$-0.0323$

(0.0020)

(0.0028)

$-0.0005$

$0.0217 * * *$

(0.0024)

(0.0083)

$-0.0002$

$-0.0099 * *$

(0.0031)

(0.0031)

0.0214

0.0210

(0.0216)

(0.0499)

$0.0028 * * *$

0.0001

(0.0006)

(0.0007)

$-0.0009$

0.0005

(0.0028)

304

(0.0036)

51

192

32

0.256

0.299

0.135

0.167

32

Yes
32

Yes

Note: Corrected robust standard errors are clustered at bank level and reported in parentheses. The p-values for the Arellano and Bond test for second order autocorrelation in the residuals (AR2), as well as the p-value for the Hansen J test are reported. $* * *, * *$ and $*$ indicate statistical significance at the $1 \%, 5 \%$ and $10 \%$ level, respectively. 


\section{Appendix}

Table A1. Sample of banks

\begin{tabular}{|c|c|c|}
\hline \# & Bank & Country \\
\hline 1 & Erste Group Bank AG & AT \\
\hline 2 & KBC Groep NV/ KBC Groupe SA-KBC Group & $\mathrm{BE}$ \\
\hline 3 & Bank of Cyprus Public Company Limited-Bank of Cyprus Group & $\mathrm{CY}$ \\
\hline 4 & Bayerische Landesbank & $\mathrm{DE}$ \\
\hline 5 & Commerzbank AG & $\mathrm{DE}$ \\
\hline 6 & DekaBank Deutsche Girozentrale AG & $\mathrm{DE}$ \\
\hline 7 & Deutsche Bank AG & $\mathrm{DE}$ \\
\hline 8 & HSH Nordbank AG & $\mathrm{DE}$ \\
\hline 9 & Hypo Real Estate Holding AG & $\mathrm{DE}$ \\
\hline 10 & Landesbank Baden-Wuerttemberg & $\mathrm{DE}$ \\
\hline 11 & Landesbank Hessen-Thueringen Girozentrale - HELABA & $\mathrm{DE}$ \\
\hline 12 & Norddeutsche Landesbank Girozentrale NORD/LB & $\mathrm{DE}$ \\
\hline 13 & Danske Bank A/S & DK \\
\hline 14 & Jyske Bank A/S (Group) & DK \\
\hline 15 & Nykredit Realkredit A/S & DK \\
\hline 16 & Sydbank A/S & DK \\
\hline 17 & Banco Bilbao Vizcaya Argentaria SA-BBVA & ES \\
\hline 18 & Banco Popular Espanol SA & ES \\
\hline 19 & Banco Santander SA & ES \\
\hline 20 & OP Financial Group & FI \\
\hline 21 & BNP Paribas & FR \\
\hline 22 & BPCE SA & FR \\
\hline 23 & Crédit Agricole S.A. & FR \\
\hline 24 & Société Générale SA & FR \\
\hline 25 & Barclays Bank Plc & GB \\
\hline 26 & HSBC Holdings Plc & GB \\
\hline 27 & Lloyds Banking Group Plc & GB \\
\hline 28 & Royal Bank of Scotland Group Plc (The) & GB \\
\hline 29 & OTP Bank Plc & $\mathrm{HU}$ \\
\hline 30 & AIB Group PLC & IE \\
\hline 31 & Bank of Ireland-Governor and Company of the Bank of Ireland & $\mathrm{IE}$ \\
\hline 32 & Banca Monte dei Paschi di Siena SpA-Gruppo Monte dei Paschi di Siena & IT \\
\hline 33 & Banco Popolare società cooperativa & IT \\
\hline 34 & Intesa Sanpaolo & IT \\
\hline 35 & UniCredit SpA & IT \\
\hline 36 & Unione di Banche Italiane Scpa-UBI Banca & IT \\
\hline 37 & Banque et Caisse d'Epargne de l'Etat Luxembourg & LU \\
\hline 38 & Bank of Valletta Plc & MT \\
\hline 39 & ABN AMRO Group N.V. & NL \\
\hline 40 & ING Groep NV & NL \\
\hline 41 & SNS Holding & NL \\
\hline 42 & Powszechna Kasa Oszczednosci Bank Polski SA - PKO BP SA & PL \\
\hline 43 & Banco BPI SA & PT \\
\hline 44 & Banco Comercial Português, SA-Millennium bcp & PT \\
\hline 45 & Caixa Geral de Depositos & PT \\
\hline 46 & Nordea Bank AB (publ) & SE \\
\hline 47 & Skandinaviska Enskilda Banken AB & SE \\
\hline 48 & Svenska Handelsbanken AB & SE \\
\hline 49 & Swedbank AB & SE \\
\hline 50 & NLB dd-Nova Ljubljanska Banka d.d. & SI \\
\hline 51 & Nova Kreditna Banka Maribor d.d. & SI \\
\hline
\end{tabular}

Note: The table reports the list of 51 banks included in the whole sample and the related country ISO-code. 